Leathes took a keen and practical interest in medical and dental education, and by reason of his work on the General Medical Council, and as dean for nine years of the Sheffield Medical School, he not only influenced his own University, but also played an important part in shaping the medical curriculum of his time. It is no more than fair to say that he, and the late Sir Arthur Hall, together were largely responsible for making the Sheffield Medical School the outstanding success it became. Their aim was to unify the medical curriculum; and they did this by weakening the barriers between the pre-clinical and chinical courses of study by extending physiology and biochemistry, with appropriate laboratories, into the ward teaching of clinical medicine-a development which has since been applied in other schools. The results of the experiment were encouraging, as also were those of an innovation which Leathes introduced into the B.Sc. course, and which consisted in making the candidates spend a further year after the fina] examination working up some special field, on which they produced a thesis, which had to be approved before the degree was granted. The average standard of these theses was surprisingly good, and the subject, in some instances, provided the new graduate with a field into which he could enter with some confidence for further study.

Leathes was elected to the Physiological Society in 1895 , and in 1952 was accorded the distinction of honorary membership. He served for three periods on its committee, and for ten years as an editor of the Journal of Physiology. This latter service, often now forgotten, was perhaps his best contribution to British physiology, for he took infinite and unsparing pains in helping authors, young and old, who lacked the ability to express themselves clearly. As he was in Toronto when the Biochemical Society was formed in 1911, he happened not to have been an original member, but he joined it in 1913.

In 1921 he was elected a fellow of the Royal College of Physicians, and gave the Croonian Lecture in 1923 ; it dealt with fat metabolism in various aspects, and in its relation to cellular structure and functions. He also gave the Harreian Oration in 1930, on "The Birth of Chemical Biology". Other honours included the D.Sc. Sheffield in 1933, and Manchester 1936, and the honorary fellowship of New College, Oxford.

Leathes was essentially a modest and scholarly man, of kindly and phlegmatic disposition, one of the few physiologists with a classical education, and a good linguist; he began the study of Russian at the age of eighty. 'lall and wiry, he was, even at that age, good for a brisk walk of ten miles or more. Among other accomplishments, he was a pastellist of discernment, despite his high degree of myopia, or perhaps even on account of it, as he was unaware of much landscape detail which tends to distract the amateur. After his retirement he moved to Wantage, and worked in the Physiological Laboratory at Oxford, with John Mellanby. Their published work, which was interrupted by the Second World War, dealt with thrombokinase, and with the action of lecithin upon it. He then moved successively to Lyme Regis, London, Southbourne, and finally to Switzerland, near the scene of some of his happier early years.

Leathes spent his life largely in helping others by patient and unselfish acceptance of responsibilities which brought no ponderable reward-service on the Council of the Royal Society, 1924-26, on the Medical Research Council, 1928-31, the General Medical Council, 1919-38, and on its Education Committee, of which he was chairman in 1931. But he will long be remembered with affection by many friends and pupils.

$$
\text { C. Lovati Evans }
$$

\section{Dr. A. E. J. Vickers}

DR. A. E. J. VICkers, who died suddenly on September 8 at the age of fifty-eight, was director of research at the Thermal Syndicate, Ltd., Wallsend, Northumberland, a position he had held since November 1947; he was elected to the Board of Directors in April 1953. His early academic education began with training in 1915 in Sheffield for the teaching profession; but, probably influenced by war work in a munitions factory, he decided to make chemistry his future profession and, following study in Stoke and London, took an external London B.Sc. in chemistry in 1922 .

He then joined the late Dr. J. W. Mellor, of the British Refractories Research Association (now the British Ceramic Research Association), Stoke-onTrent, where he developed an interest in mineralogy, and in 1927 he took the post of chief chemist to Buxton Lime Firms Co., Ltd. (now the Lime Division of Imperial Chemical Industries, Ltd.). Two years later Dr. Vickers moved to the Billingham works of Imperial Chemical Industries, Ltd., and continued investigations in the problems of refractories and in mineralogy, gaining his Ph.D. in 1935 with a thesis on the colloidal properties of clay. During the latter part of his stay at Billingham he was in charge of research on ceramics, mineralogy and physical methods, including a variety of applications of spectroscopy and microscopy, and when he moved in 1947 to the Thermal Syndicate, Ltd., his work ccntinued to be largely in the field of ceramics, but at higher temperatures than heretofore.

Dr. Vickers was keenly interested in the work of scientific and technical societies, including the Royal Institute of Chemistry, the Society of Glass Technology and the Society of Chemical Industry, and he was a founder member of the Institute of Ceramics. He was also very much concerned with higher education, being a member of the council of St. John's College in the University of Durham. Apart from his professional work, Dr. Vickers was a keen photographer, gardener and musician, and he was an active member of the Anglican Church. $\mathrm{He}$ is survived by his wife and by a son and a daughter, training respectively for the medical and dental professions.

\section{Prof. B. M. Duggar}

BenJamin Minge Duggar, botanist, mycologist, plant physiologist, plant pathologist and microbiologist, who died at New Haven, Connecticut, in mid-September, a fortnight after his eighty-fourth birthday, had a long and varied career. After holding posts in his native state of Alabama and elsewhere, Duggar became professor of botany in the University of Missouri in 1902. Afterwards he was professor of plant physiology first at Cornell (1907-12) and then in the University of Washington (1912-27), from where he moved to the University of Wisconsin as professor of plant physiology, plant pathology and economic botany (1927-43). Finally, in 1944, he became consultant on mycological research and production to the Lederle Laboratories Division of the American Cyanamid Co. 